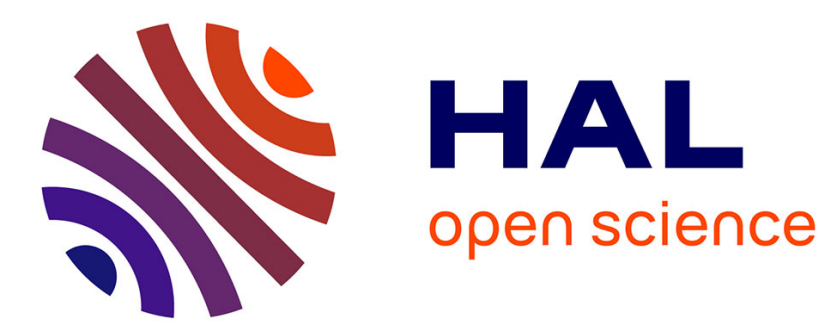

\title{
The equalising mirage? Socioeconomic segregation and environmental justice in post-socialist Bucharest
}

Samuel Rufat, Szymon Marcińczak

\section{To cite this version:}

Samuel Rufat, Szymon Marcińczak. The equalising mirage? Socioeconomic segregation and environmental justice in post-socialist Bucharest. Journal of Housing and the Built Environment, 2019, 35, pp.917-938. 10.1007/s10901-019-09722-7 . halshs-02485390

\section{HAL Id: halshs-02485390 \\ https://shs.hal.science/halshs-02485390}

Submitted on 28 Apr 2021

HAL is a multi-disciplinary open access archive for the deposit and dissemination of scientific research documents, whether they are published or not. The documents may come from teaching and research institutions in France or abroad, or from public or private research centers.
L'archive ouverte pluridisciplinaire HAL, est destinée au dépôt et à la diffusion de documents scientifiques de niveau recherche, publiés ou non, émanant des établissements d'enseignement et de recherche français ou étrangers, des laboratoires publics ou privés. 


\title{
The equalising mirage? Socioeconomic segregation and environmental justice in post-socialist Bucharest
}

Journal of Housing and the Built Environment, 35, 917-938 (2019), doi: $\underline{10.1007 / \mathrm{s} 10901-019-09722-7}$

Samuel Rufat, Institut Universitaire de France, Univers ité de Cergy-Pontoise, France, samuel.rufat@u-cergy.fr

Szymon Marcińczak, University of Łódz, Poland, szymon.marcinczak@geo.uni.lodz.pl

\begin{abstract}
Unlike the vast majority of European capitals, and despite growing income inequality, descriptive measures of socioeconomic segregation seem to show a desegregation trend in Bucharest over the last two decades. Socioeconomic segregation and environmental justice studies provide completing insights of the intricated uneven geographies of social, economic and environmental disparities of post-socialist cities. And Bucharest is paradoxically the most populated and yet less studied of the capitals of Central and Eastern Europe. This paper explores changes in the patterns of socioeconomic segregation in post-s ocialist Bucharest, sheds more light on the relationship between neighbourhood characteristics and the patterns of segregation, and includes 'attractor' and 'repellent' environmental factors, contributing to combine environmental justice and socioeconomic segregation approaches. Despite the apparently continuous desegregation trend, and even when controlling for the presence and proximity of other predictors, environmental factors play an increasing role in shaping local socioeconomic segregation patterns. This would suggest the need for consideration of the environmental factors in public policies aimed at mitigating the social cost of the transition and residential segregation. This should also lead to use descriptive measures of segregation more cautiously and to explore the relationship between neighbourhood characteristics, environmental conditions and the local patterns of segregation instead.
\end{abstract}

\section{Keywords}

socioeconomic segregation, environmental justice, post-s oc ialist, Bucharest 


\section{Introduction}

Soc ioeconomic, income or class-based segregation has been on the rise in Europe and North America for the past two decades (Florida 2017, Marcińczak et al. 2016). On both sides of the Atlantic, the deepening of socio-spatial divisions has its roots in growing income inequality. Whereas the results from the U.S. (Reardon and Bischoff 2011) and Western Europe (Musterd et al. 2016) illustrate that rising socioeconomic segregation closely follows growing income disparities, the effect of economic inequality on spatial divisions seems to differ in former socia list countries (Marcińczak et al. 2015). Whether time-lagge d or not, the relationship between income and segregation is mediate $d$ by a multitude of structural factors, especially the type and extent of welfare provision and the form of housing system (Arbaci, 2007; Maloutas and Fujita, 2012).

Whilst socioeconomic segregation has been extensively studied in Europe (Tammaru et al. 2016), there still rema in some issues to be addressed. First, the majority of studies on class and income-based segregation rely on descriptive indices of segregation and put emphas is on structural factors in explaining the evolving global patterns of socio-spatial divisions (Musterd et al. 2016). Such studies disregard the effect of neighbourhood characteristics on local patterns of segregation, their changes, and the ir contribution to the evolution of global segregation patterns (Brown and Chung, 2008). Then, the recent attempts to link neighbourhood characteristics to the spatial patterns of socioeconomic divisions in post-socialist cities have left the role of environmental factors unexplored (Marcińc zak et al. 2017). And the currently mixed findings regarding the association between segregation and environmental exposure might be linked to serious methodological issues (Frey, 2017). Finally, even recent studies on residential segregation and environmental justice do not inc lude cases from South-Eastern Europe (Maloutas and Fujita, 2012; Tammaru et al. 2016), where the transition from socialism to capitalis $m$ was much slower than in the countries that joined the European Union in 2004 (Hamilton et al., 2005). The paper has thus the following aims: 1) to explore changes in the global and local patterns of socioeconomic segregation in post-soc ialist Bucharest over the last two decades; 2) to shed more light on the relationship between the spatial concentration of social categories and different neighbourhood characteristics; 3 ) to include 'attractor' and 'repellent' environmental factors in order to combine environmental justice and socioeconomic segregation approaches in the post-socialist context.

European post-socialist cities have suffered from severe environmental issues due to massive industrialisation, hasted socialist urbanisation and the political suppression of environmental movements during the communist rule, as well as poor post-socialist environmental protection legis lation (Pavlínek and Pickles, 2000; Whitehead, 2005). 
People who live close to green spaces are more likely to benefit from ecosystem functions lowering such adverse impacts (Chaisty and Whitefield, 2015). Conversely, people living close to industrial areas are more likely to be exposed to pollution, noise and hazards (Suditu and Vâlceanu, 2013) and are pushed to make different locational choices (Cook and Swyngedouw, 2012). As environmental conditions render neighbourhoods more (symmetrically less) desirable to the socialclass that has the choice of residential mobility (Easzkiew icz et al., 2017), they might therefore percolate into the socioeconomic segregation patterns.

Bucharest is somewhat paradoxically the most populated and yet less studied of the capital cities of Central and South-Eastern Europe (Marcińczak et al. 2014). Shedding more light on the evolution of segregation patterns in South-Eastern Europe might help to better understand the link between the pace of massive political shifts, socioeconomic inequality, environmental justice, and the mutating geography of socioeconomic segregation. Bucharest is of particular interest in this respect, because of the gradualist context of post-socialist transition in Romania - only entering the EU in 2007, the more 'hardline' communist rule until 1989, and Ceauşescu's large-scale socialist redevelopment of the city centre.

\section{Study area}

Bucharest has about two million inhabitants, making the capital of Romania the largest city in the former socialist countries of Central and South-Eastern Europe. It has a population density of more than 8,000 persons $/ \mathrm{km} 2$, with up to 15,000 persons $/ \mathrm{km} 2$ in large housing estates developed under communist (Ianoş et al., 2016). The city is divided in six sectors radiating from the city centre as pies shares (Figure 1). They each have their own city hall, mayor, and assembly, but administrative boundaries do not take neighbourhoods into account and sometimes cut through the middle of a block (Che lcea et al., 2015). Metropolitan areas have no legal status in Romania, there is no institutional arrangements for cooperation with the neighbouring towns. And within the Munic ipality of Bucharest itse If, the local governments are not always coordinated as it is not uncommon for its 6 sectors and to be governed by opposing parties (Dumitrache et al., 2015).

At the fall of the communist regime, Bucharest concentrated $70 \%$ of its population in large soc ialist housing estates. As in neighbouring countries, the Romanian economy experienced a significant decline in the 1990s, followed by a rapid growth in the 2000s, until the 2009 crisis. However, Romania's path is different, with a hardline communist rule, and, in Bucharest, low-density central neighbourhoods with socially mixed populations were torn down to build Ceauşescu's gigantic "Civic Centre" (Chelcea, 2006). After 1989, reforms were delayed, the inflow of foreign investment was uncertain, 
and employment in large state-owned enterprises remained more or less intact until 1996, when the liberals won the elections with a program of privatisation and euromodernisation. During this "hes itant transition" (Marcińc zak et al., 2014), neither the privatisation nor the restitution of properties nationalised in 1948 created full bundles of private property rights. Starting from 1991, most state-owned hous ing was privatised, selling apartments and old houses to sitting tenants at deflated prices, regardless of location, quality, or architectural value. In 1995, the state legislated protection aga inst eviction for 10 years, banning the alienation of tenants, and imposing "rent caps"; residential mobility was thus low and the housing market ridged (Chelcea et al., 2015). In the second half of the 1990s however, the privatisations triggered a sharp deindustrialisation, from about 430,000 employees in 1990 to 200,000 in 2000 and 130,000 in 2010, and the population begin to steadily decrease (Table 1).

\section{Figure 1. Map of the 6 sectors of Bucharest showing the forest, lakes, green areas} and indus trial land in 1992.

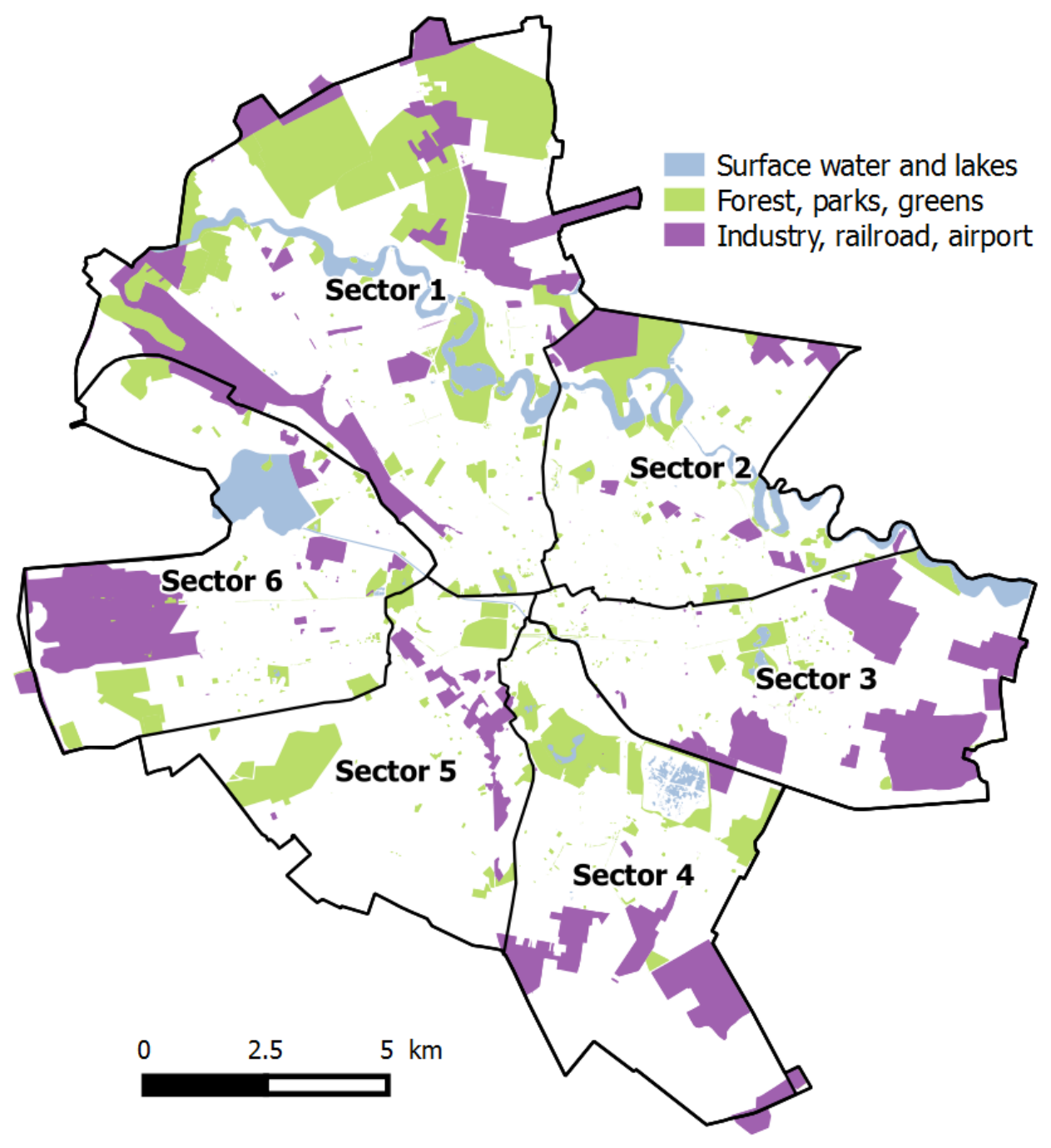


The beginning of the 2000s saw a new round of reforms, with the new constitution securing private property rights in 2003 , the ban on the selling of privatised houses ending in 2005, and the 2006 law establishing a mortgage market. This led to a real estate bubble in Romania between the $2007 \mathrm{EU}$ accession and the 2009 crisis (Dumitrache et al., 2015). In Bucharest, most investments were focused on converting former industrial land into office buildings, malls, shopping centres, and occasionally gated communities near the northern lakes or luxury condos in the central areas (Ianoş et al., 2016).

Table 1. Bucharest, city social profile $1992-2011$.

\begin{tabular}{|l|r|r|r|}
\hline & \multicolumn{1}{|c|}{1992} & \multicolumn{1}{c|}{2002} & \multicolumn{1}{c|}{2011} \\
\hline Total population & $2,067,545$ & $1,926,334$ & $1,883,425$ \\
\hline Working population & 937,298 & 825,655 & 893,501 \\
\hline Higher Socio Professional Categories (\%) & 18.0 & 28.4 & 38.2 \\
\hline Medium Socio Professional Categories (\%) & 32.9 & 35.5 & 37.9 \\
\hline Lower Socio Professional Categories (\%) & 51.5 & 36.1 & 23.9 \\
\hline
\end{tabular}

The North of the city concentrates most parks and forests, and while green spaces tend to be of smaller size in the city centre, the large park around the Civic Centre stands out (Figure 1). Other large parks adjoin the large socialist housing estates from the 1960s and 1970s, notably to the South East and the East, whereas orchards and meadows are more present at the periphery. The authorities lacked the resources to maintain the parks during the economic shock of the first decade of the transition (Pătroescu et al. 2011). Some of the parks greens remained wilderness parks and stray dogs to playgrounds and amenities until the 2000s (Iojă et al, 2011), despite the creation of new Văcarești National Park around the reservoir in the south east of the city (Ianoş et al., 2016). However, regardless of their design, maintain or state of disrepair, all green spaces were found protective of the smog and urban heat is land correlated with the high $r$ ise building stock (Sirodoev et al, 2015).

Before the socialist period, the first wave of industrial expansion went to the south (Rahova) and west (Griviţa) of the city center (Simion, 2016). During the socialist transformation, massive industria lization continued throughout the 1960s and 1970s, concentrating the heavy industry chosen by Ceauşescu in massive industrial complexes along the major axes towards the outskirts of the city, westward (Militari), southward (Progresul), and eastward (Republica) (Figure 1). A lighter industry was developed along the railway lines towards the northwest, and near the Băneasa airport in the north. Even though higher and denser housing estates were hastily constructed in the proximity of the massive industrial complexes, the Obor (1966), Titan (1967), Militari (1968) and Rahova (1970) housing complexes, the housing sector increasingly lagged behind the growth of industrial employment. Consequently, the peripheral zone was gradually taken over by 
self-provided wood and cob housing lacking bas ic amenities (Marcińczak et al. 2014). The industrial complexes have been closing down since the end of the 1990s, with a mix of abandoned buildings and partial reconversion of the better connected estates. Privatisation ga ine d momentum in the 2000s, plants with good transport accessibility proved to be more valuable as real estate rather than production and were redeveloped into business parks, hypermarkets and shopping malls (Simion, 2016) that were previously nonexistent in socialist cities. Nevertheless, current and former industrial land is still affected by heavy water and soil pollution (Grădinaru et al., 2014). And in 2011, Bucharest was still hosting 14 Seveso hazardous industrial sites, some of which are located near the city centre - as the Grozavești power plant exposing the presidential palace (Rufat 2013). Recent housing projects are also impacted by the proximity of industrial land and obnoxious facilities: in 2008, the National Housing A gency (ANL) launched a social homeownership assistance program of over 1,000 small houses on a 115 ha strip along the Băneasa airport runway.

Figure 2. Change in the distribution (\%) of the ISCO profiles in Bucharest $1992-2011$.

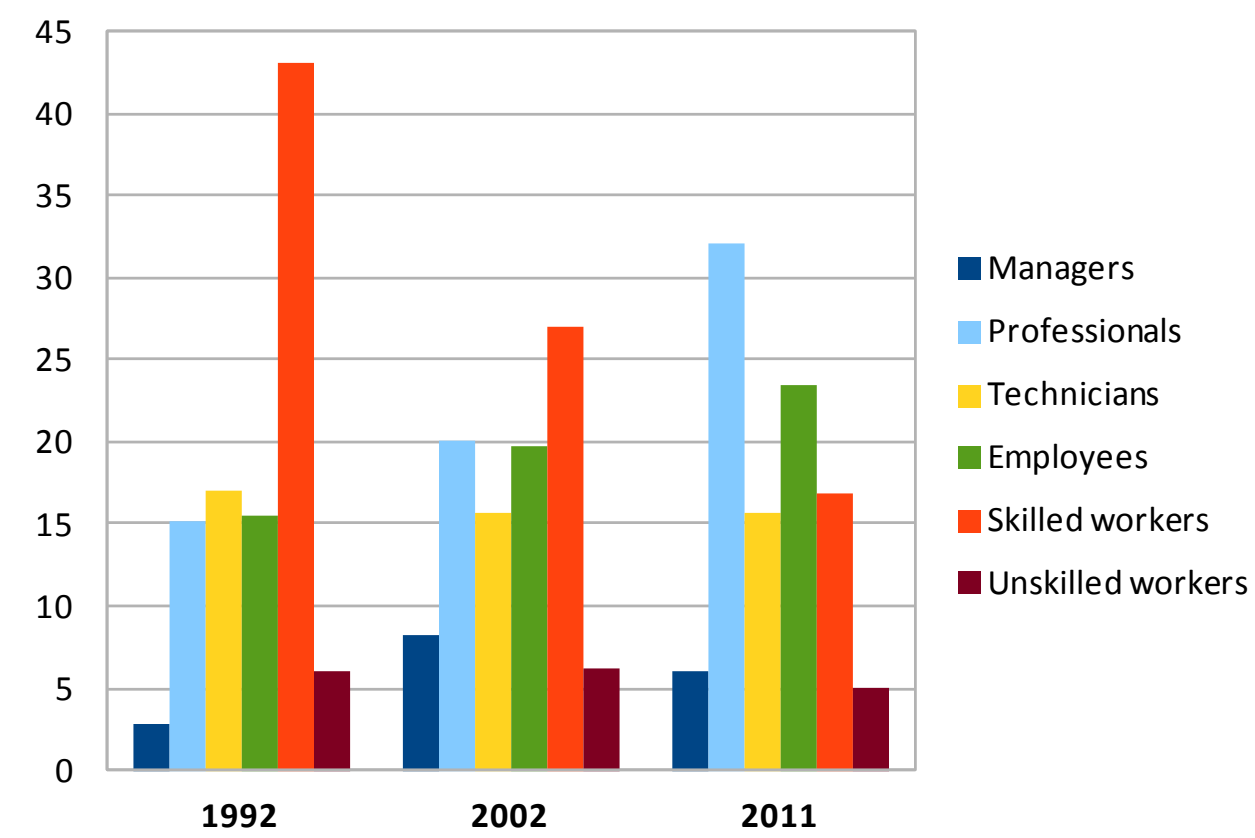

Like other post-socialist cities, Bucharest recently entered the second demographic transition with a population decline and an increase of older people. Bucharest's economy has tertiarised and with the coming to age of a more educated new generation, the share of individuals with little or no education has decreased. The evolution of the employment structure reflects the steady decline of employment in industry and the professionalisation of the workforce, resulting in a more mixed social profile (Figure 2). 


\section{Environmental justice and socioeconomic segregation}

Whilst the rise of inequalities has been especially acute during the first decade after socia lism (Hamilton et al., 2005), the level of socioeconomic segregation did not seem to change in European post-socialist cities during the 1990s, leading to the idea of a "delayed segregation" (Sykora, 2009). In most of them however, a strong re lationship between the social composition and the built environment of neighbourhoods has been highlighted, both under socialism and after (Sta linov, 2007). Usually undermainta ined and decaying, the pre-socialist hous ing stock dominating in the historical centre and the peripheral zone accommodated the lower social categories. Conversely, socialist-era housing estates and some inner-city villa neighbourhoods were home to the higher and middle social groups (Sykora, 2009). The 2000s then saw the social upgrading of city centres (Bernt et al., 2015) and the migration of upper social categories to newly built housing and the suburbs (Stanilov and Sykora, 2014). Although not all soc ia list housing estates have deteriorated, and while many were hastily built, of poorer quality and lacking amenities, some districts were planned according to grand visions, in coordination with industrial complexes and with attention to greenery, those blocks of flats have gradually been losing their better-off residents (Kovacs and Herfert, 2012). These trends have led to much speculation on the deepening of socio-spatial divisions, the polarisation or even the dua lisation of urban space. The "delayed segregation" has finally started to materialise in some post-socialist cities in the 2000s, as socio-spatial divisions started to rise, catching up with income disparities. However, twenty-five years after the end of communis m rule, post-socia list cities are still not pointing towards a socio-spatial dualisation of urban areas (Marcińczak et al., 2016).

Currently, most studies work under the implic it assumption that spatial differentiations do not influence segregation, but are rather a result of segregation. Some authors have however been making the opposite argument, as there is a time lag between the slow change of the physical structures, built environment and environmental quality of neighbourhoods over time and the often much faster change in population characteristics and demand for residence. This is especially true in central cities with old and sometimes dilapidated and obsolete housing, and especially in Europe, where urban development might be highly regulated by housing policies and urban planning, which interfere with the processes of market segregation (Andersen 2003, van Kempen et al. 2009). And such temporal discrepancies are even more true in cities that have experienced socialist rule and transformations, whose requirements contrasted with existing pre-socialist physical structures, whereas then the socialist urban fabric was in turn found to be less suitable for the needs of the following period, while experiencing the profound population

characteristic transformation and demand for residence change of the post-socialist period (Hamilton et al. 2005, Stanilov et al. 2014). Andersen (2003) for example says that one of the main reasons for abandonment and low demand for housing in these areas is that the decaying environment prompts a high turnover of residents and failing interest. More 
recently, some authors have proven the local context to be critical in the production of the patterns of segregation (Ma loutas et al. 2012) and started to explore the relationship between various neighbourhood characteristics and the local patterns segregation (Musterd et al. 2016, Marcińczak et al. 2017), even if for the time being the effect of environmental factors on the local patterns of socioeconomic segregation have been less studied.

While there has been little focus in the segregation literature on the importance of the physical, environmental and economic spatial structure beyond hous ing tenure and housing markets, early environmental justice studies focused on the residential neighbourhoods of socially marginalized people and the ir proximity to noxious resources and facilities (Bullard 1990, Helfand et al. 1999). From the seminal works of Zorbaugh on access to amenities, and of Bullard on exposure to toxic facilities, environmental justice studies have highlighted the uneven distribution of exposure to hazards (Davis, 2006), pollutants (Morello-Frosch and Jesdale, 2006), noise (Houston et al., 2014) or unwanted land uses (Mohai and Saha, 2006) among soc ial classes and environmental racism (Taylor, 2014). Bullard noted that socially marginalized groups choices tended to be based on cost rather than environmental quality, expla ining why they tend to "choose" hazardous or obnoxious neighbourhoods (1990). Some have expressed doubts on such unidirectional causa lities, claiming that the relationship between individuals and the ir environment is in fact mutual (Massey, 2005), leading to a broader focus on the characteristics of local contexts and places where racial groups reside (Landrine and Corral, 2009).

As an extension of these residence-based studies in the environmental justice literature, several researchers argued that residential segregation may be perpetuating inequalities in environmental exposure and health (Park et al. 2017). Such empirical studies have been us ing a variety of environmental variables to study the differential exposures and access of different groups, ranging from green space availability (Laszkiewicz et al. 2017) and distance (Czembrowski et al. 2016) to normalized difference vegetation index (NDVI) (Saporito et al. 2015) or ecological diversity index and ecosystem services (Cohen et al. 2012), density of urban trees (Frey, 2017), air pollution concentrations (Padilla et al. 2014), automobile and truck traffic and emissions (Houston et al. 2014), noise levels (Casey et al. 2017), soil lead concentrations (Aelion et al. 2015), presence of waste and polluting facilities (Boone et al. 2014), distance to waste treatment, storage and disposal facilities (Mohai et al. 2006), etc. Some even discussed that favoured and well educated populations might make the choice to live in expens ive and polluted areas because they are closer to other amenities (Padilla et al. 2014), while South et al. (2011) found no relation between the ecological structure and spatial segregation. Empirical studies have thus reported incons istent results, ranging from a strong association to no association, or even negative correlations - ie increasing exposure to some pollutants associated to decreasing residential segregation (Morello-Frosch et al. 2006). 
Environmental justice studies began to use measures of residential segregation only recently, and thus far the ir results have not been consistent (Park and Kwan, 2017), explaining why the ir findings have not fully percolated into segregation studies. And recent studies in the US have raised methodological issues linked to spatial autocorrelation, multicollinearity and heteroskedastic ity, casting some doubts on previous findings (Boone et al., 2014; Frey, 2017). Similarly, recent works on the effects of neighbourhood characteristics on local patterns of segregation are generally aspatial, or not controlling for spatial autoc orrelation (Musterd et al. 2016, Marcińczak et al. 2017) the analysis generally ignores the proximity between tracts. Moreover, in an exploratory approach, many studies have been multiplying the number of models and variations, and/or increasing the number of variables implemented in each model, and such a variable inflation is raising Type I error, overfitting, multic ollinearity and heteroskedasticity issues (Bland et al. 1995). Socioeconomic segregation and environmental justice studies are thus currently facing similar methodological issues, yet they could provide completing insights of the intricated uneven geographies of social, economic and environmental disparities of post-socialis t cities.

While previous publications have been using environmental indicators as dependent variables, our own comprehensive study design was configured the other way around: us ing environmental factors as independent variables or 'predictors' of the local patterns of segregation. In order to shield our findings from previous methodological issues we made sure to limit the amount of variables implemented in the analys is by first studying the correlations among them, to use spatially explic it models addressing both presence within the selected tract and proximity in neighbouring tracts, to report a wider range of p-values, and to use regression diagnostics to control spatial autocorre lation (Moran's I statistic), multicollinearity (Multic ollinearity Condition Number) and heteroscedastic ity (Breusch-Pagan test).

\section{Methods and research material}

\subsection{Geography and research materials}

We used the last three Romanian censuses $(1992,2002,2011)$ to calculate the indices of segregation and to characterise the neighbourhoods. However, the number of census tracts has reduced, from 160 tracts in 1992, to 151 in 2002, and to 131 in 2011, while most boundaries were redrawn. As a result, direct comparison between the censuses would suffer from the MAUP problem. Whilst some authors have consequently only relied on the six sectors because their boundaries remained stable (Armaş et al., 2016), we consider that scale too crude to adequately monitor the patterns of neighbourhood change. We therefore aggregated the census data into the smallest contiguous and 
spatially invariant ensembles. The resulting 39 districts allow for less biased comparison between the three censuses. We also used land usage data from the Romanian National Statistics Institute to compute the share of green space and the share of industrial land of the different spatial units at those dates. However, national censuses in post-socialist countries may not cover all residents actually living in a city (Steinfuhrer et al., 2010). They usually fail to register population categories such as home less people, squatters, ille gal immigrants or students still registered at the ir parents' homes. The data quality of the 2011 census has been further questioned, ma inly because of a political call to boycott the census that might have led about $5 \%$ of the population of Bucharest to evade it (Anonymous and Rufat, 2015). Some have even claimed that those data qua lity and comparison issues might be on purpose (Armaş et al., 2016).

As for socioeconomic categories, we merged the eight original ISCO categories into higher and lower social groups. We incorporated the two highest social categories (managers and professionals) to form the higher group. Likewise, we combined unskilled workers, skilled workers and machine operators to form the lower group. The remaining ISCO categories, technicians, civil servants and service workers were included in a medium social category (Table 1). Although somewhat basic, owing to the fact that the gap between the rich and the poor is widening across cities in Europe (Musterd et al. 2016), we laid the emphasis on the evolving patterns of segregation of the higher and lower social groups.

\subsection{Methods}

In the first stage of empirical analys is, we used descriptive measures of segregation. The index of diss imilarity (ID) was used to measure the global patterns of segregation. It takes values from 0 to 1 , with higher values indicating a more uneven distribution of groups. The Modified Index of Isolation (MII) was calculated for the higher and the lower social groups to estimate how (un)evenly each group is distributed compared to the remainder of the population while taking into account the ir relative size. As for ID, low values of MII indicate weak isolation of a social group; high values, above 0.6 , signal strong spatial is olation. The Location Quotient (LQ) was used to pin down local patterns of segregation, understood as the degree of a group's relative concentration in a neighbourhood (at different scales). Positive values with one standard deviation above the mean indicate that a group is significantly overrepresented in a given tract. We also use this index as the dependent variable in the subsequent regression models.

In the second stage of the empirical analys is, we employed the econometric approach to explore the relationship between the local patterns of socioeconomic segregation and the demographic, housing and environmental characteristics of neighbourhoods in 1992, 2002 and 2011. We estimated multivariate OLS models with LQ values at the census tract level for the higher social group as the dependent variables. The same analys is was conducted for the lower social category and repeated for each census year. In the six 
resulting regression models, the Moran's I tests confirmed the presence of spatial autocorrelation $(\mathrm{p}<0.05)$. In all these models, the robust Lagrange Multiplier test suggested the spatial lag model as the best alternative. In order to allow for robust comparison, we repeated the whole process at the district aggregation scale. At this scale, we proceeded with the results estimated by OLS, as we did not detect spatial autocorrelation in the residuals of the models.

\subsection{Variables selection and description}

The local patterns of soc ioeconomic segregation in the former socialist city are related to the different demographic, building stock and housing characteristics of neighbourhoods (Marcińc zak et al. 2015). Our innovative approach added environmental variables to test the effects of nearby environmental factors on local patterns of segregation while controlling for the presence and proximity of demographic, building stock, and housing condition factors. We first selected the 10 demographic variables most in use in the literature that were available for all three census dates $(1992,2002,2011)$, then added four variables on the building stock (built before 1945, 1945-1977, 1977-1989, after 1990), three variables on the housing condition (lack of running water, lack of toilets, wood and cob) and three environmental variables (share of industrial land, share of lakes, and share of green spaces). As some of those 20 variables are highly correlated with each other, we had to scale down to the two less correlated variables per domain (demography, building stock, housing condition and environment) and had to further take out household composition due to its strong correlation to age in order to avoid the potential problem of multicollinearity. Table 2 presents the 7 remaining variables along with the ir expected effects and descriptive statistics.

Table 2. Selection of variables

\begin{tabular}{|c|c|c|c|c|c|c|c|c|}
\hline \multirow{2}{*}{ Variables } & \multirow{2}{*}{$\begin{array}{l}\text { Theoretical } \\
\text { effect on } \\
\text { High }\end{array}$} & \multirow{2}{*}{$\begin{array}{l}\text { Theoretical } \\
\text { effect on } \\
\text { Low }\end{array}$} & \multicolumn{2}{|c|}{ Mean 1992} & \multicolumn{2}{|c|}{ Mean 2002} & \multicolumn{2}{|c|}{ Mean 2011} \\
\hline & & & tract & district & tract & district & tract & district \\
\hline Over 65y & + & - & $11.4 \%$ & $11.3 \%$ & $14.5 \%$ & $14.0 \%$ & $15.6 \%$ & $14.7 \%$ \\
\hline Before 1945 & + & - & $34.9 \%$ & $41.9 \%$ & $34.3 \%$ & $37.9 \%$ & $20.2 \%$ & $21.9 \%$ \\
\hline After 1990 & + & - & $4.1 \%$ & $0.6 \%$ & $9.1 \%$ & $9.6 \%$ & $12.8 \%$ & $16.0 \%$ \\
\hline No running water & - & + & $7.9 \%$ & $9.9 \%$ & $5.6 \%$ & $7.1 \%$ & $1.3 \%$ & $1.4 \%$ \\
\hline Rent & $-/+$ & $+1-$ & $39.3 \%$ & $37.6 \%$ & $9.5 \%$ & $10.5 \%$ & $5.3 \%$ & $4.9 \%$ \\
\hline Green areas & + & - & $9.0 \%$ & $11.7 \%$ & $7.2 \%$ & $10.3 \%$ & $6.0 \%$ & $9.1 \%$ \\
\hline Industrial land & - & + & $14.8 \%$ & $14.6 \%$ & $8.0 \%$ & $12.6 \%$ & $4.8 \%$ & $11.6 \%$ \\
\hline
\end{tabular}

Demographic factors: "elderly (residents aged 65 and more)" was used as a predictor for high soc ial status areas. The elderly were already concentrated in the better quality housing in the central area under socialis $m$ and were able to stay there at least until the 
2002 census (Chelcea et al., 2015). This variable was also strongly associated with the share of smaller households (singles) and negatively correlated with the share of larger households (with more than five people), children (less than five and less than 14 years old), lack of education (no school diploma), and low quality housing (buildings made out of wood and cob). As a result, the variable was expected to be a predictor of neighbourhoods with high social status - at least until 2002 - as is the case in the centre of other capital cities at least during the first years of the post-socialist transition (Marcińc zak et al., 2014).

Building stock factors: "buildings constructed before 1945" was used as a predictor of high social status areas. The older buildings in more prestigious locations were subject to initial gentrification (Chelcea, 2006), and the process of social upgrading in the historical housing stock gained momentum in the 2000s (Chelcea et al., 2015). The "buildings constructed after 1990" variable was also expected to correlate with high social status, as it is the case in other post-socialist countries (Holm et al, 2015; Marcińczak et al., 2017). We chose to keep both ends of the construction date - before 1945 and after 1990 - as they were retaining the most information and consistent with previous studies of presocia list, socia list and post-socia list transformation (Kovacs et al. 2012).

Housing factors: "lack of running water in the housing" was used as the predictor of lower social status areas according to the results of factorial ecology studies from Romania (Rufat 2013) and Poland (Marcińczak and Sagan 2012). It was positively correlated to the other housing variables (lack of toilets and housing in wood and cob), so it is also an indicator of a larger situation of deprivation. As housing ownership usually relates to higher soc ial status, living in public housing is linked to welfare dependency, and renting is the most frequent predictor of lower social status in post-socialist contexts (Holm et al. 2015), we also used the variable "share of residents renting apartments" as an indicator of the housing tenure.

Environmental factors: the share of surface water and lakes (derived from 2006 imagery) was each time strongly positively correlated with the share of green areas, including parks, forest, cemeteries, orchards, and meadows, based on inventories from previous studies, with a small time lag: 1995, 2000 and 2010 (Pătroescu et al. 2011). As the presence, distance or share of green areas are the most used indicators of environmental quality, access to amenities and expos ure in environmental justice studies (Frey, 2017), we chose the "share of green areas" as our 'attractor' indicator of environmental quality. For the our 'repellent' indicator of exposure to environmental noxiousness, we couldn't find direct data (air and soil pollution concentrations) consistently for each of the three census years, as a result we have chosen the most in use proxy in the environmental justice studies: exposure to industrial, waste and polluting facilities (Mohai et al. 2006, Boone et al. 2014). Based on inventories from previous studies, we used "share of industrial land", airport and railroad land, and industrial brownfield until the date of the ir 
actual conversion to other uses (Simion, 2016) to account at once for exposure to air pollution, soil pollution, waste, hazards and noise. Recent studies based on hedonic pricing models have confirmed that whilst industrial land has a depressive impact on real estate value, people are willing to pay more to live close to parks or forests (Ardeshiri et al., 2016; Czembrowski and Kronenberg, 2016; Panduro and Veie, 2013). As a result, without a strong hous ing policy, the less privileged will be pushed away from green spaces and will only be able to afford to live near less desired spaces (Basolo and Yerena, 2017). In other words, correlating green space and industrial land uneven geographies with the dynamics of residential segregation can reveal that the lower socioeconomic group are being "trappe d" in environmental exclusion because of the ir inability to access to residential mobility (Coulter and van Ham, 2013).

\section{Results}

\subsection{Separation and concentration of socioeconomic groups}

Table 3 shows the results of two global segregation indices summaris ing the degree of socio-spatial divisions in the city. The steadily decreasing ID values reveal that the spatial gap between the top and bottom social categories is narrowing. So, unlike the vast majority of European capital cities in the first decade of the twenty-first century (Musterd et al. 2016), and irrespective of growing income inequality, the segregation between the opposing soc ioeconomic categories seem to have decreased. The trend was in progress over the two decades after the collapse of socialism, and it can be confirmed at different spatial scales (tracts and districts).

Table 3. Indices of segregation for Bucharest 1992 - 2011 at different scales

\begin{tabular}{|c|c|c|c|c|c|c|}
\hline \multirow{2}{*}{} & \multicolumn{2}{|c|}{ ID } & \multicolumn{2}{c|}{ MII higher } & \multicolumn{2}{c|}{ MII lower } \\
\cline { 2 - 7 } & tract & district & tract & district & tract & district \\
\hline 1992 & 0.34 & 0.29 & 0.1 & 0.06 & 0.1 & 0.020 \\
\hline 2002 & 0.32 & 0.26 & 0.08 & 0.06 & 0.06 & 0.042 \\
\hline 2011 & 0.26 & 0.24 & 0.05 & 0.05 & 0.04 & 0.003 \\
\hline
\end{tabular}

The results of MII further confirm this trend. In spite of massive shifts in the employment structure, we notice lowering levels of concentration of both socioeconomic categories. The segregation patterns of the higher socioeconomic group appear to be less micro-scale and fragmented, as there is not much difference between the smaller tract and the larger district scale. And in general, the smaller the aggregation unit, the higher the value of the global indices (Wong et al., 1999). 


\subsection{Spatial patterns of differentiation}

The Location Quotients (LQ) were mapped in quartiles for both the high and low social groups for each census year $(1992,2002,2011)$ at the tract and district scale. At the tract scale, the patterns of segregation are consistent over time with a concentration of the high social group in the central and northern neighbourhoods and the low social group clustering in the outskirts (Figure 3).
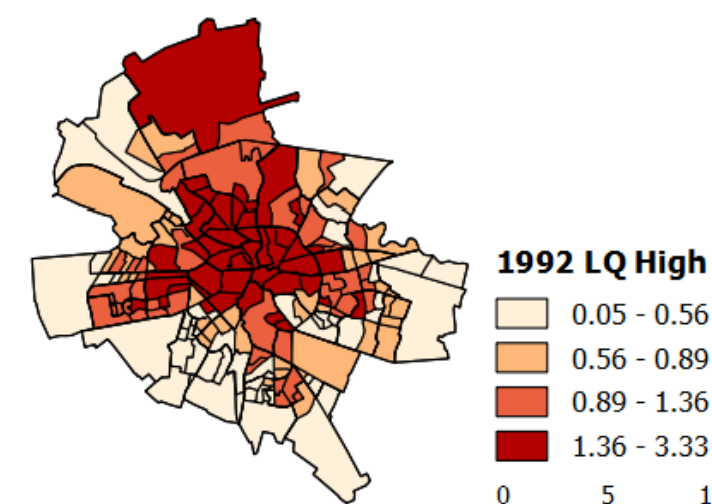

$0.56-0.89$

$0.89-1.36$

$1.36-3.33$

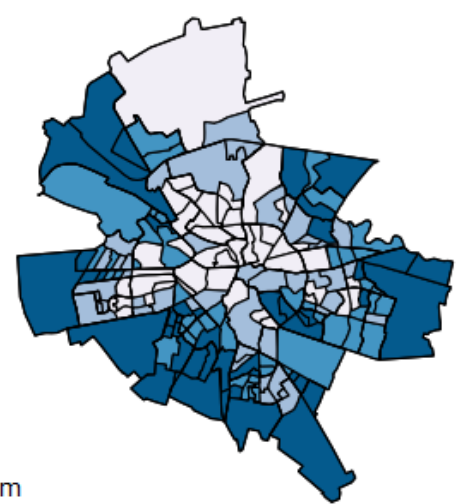

1992 LQ Low

$\begin{array}{r}\square \\ \square\end{array} 0.29-0.80$
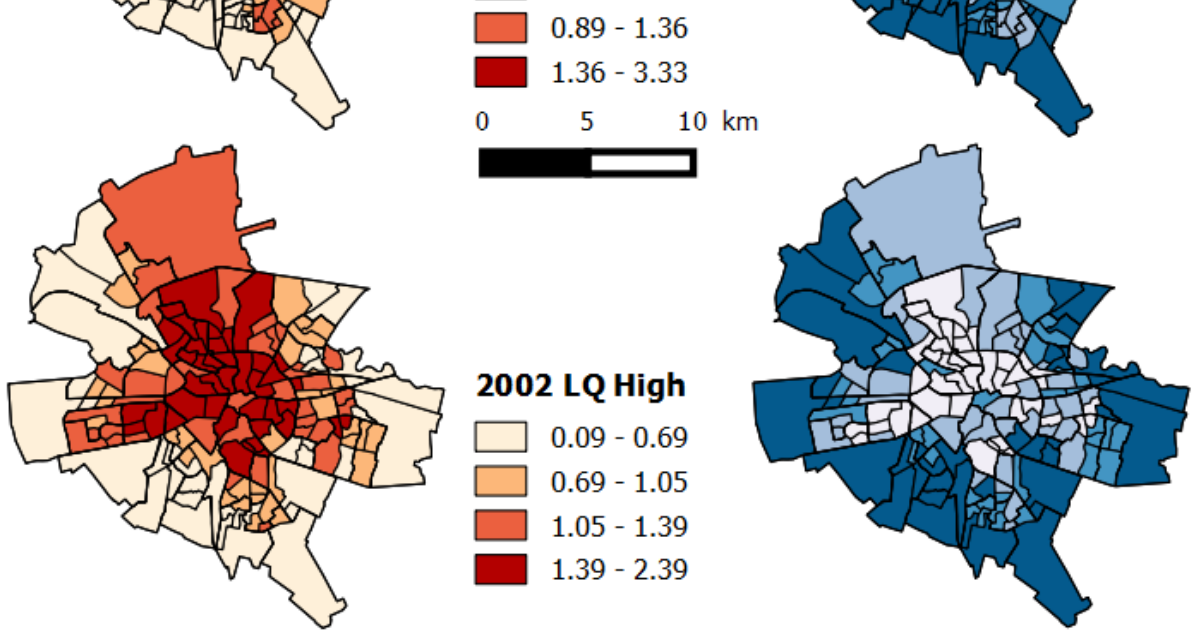

2002 LQ High

$0.09-0.69$

$0.69-1.05$

$1.05-1.39$

$1.39-2.39$

2002 LQ Low

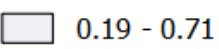

$0.71-0.95$

$0.95-1.15$

$1.15-2.01$
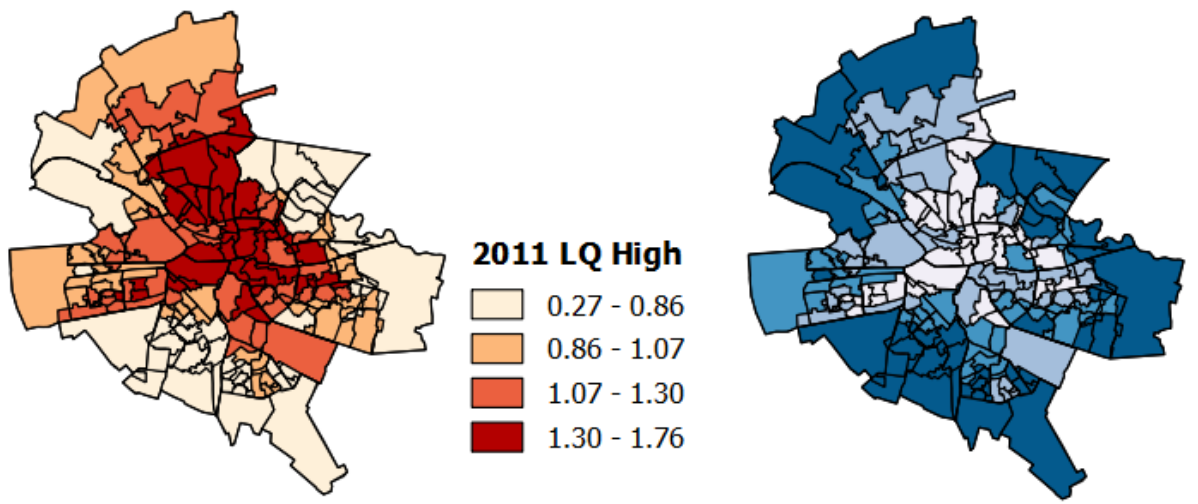

2011 LQ Low

$0.31-0.70$

$0.70-0.87$

$0.87-1.10$

$1.10-1.98$

Figure 3. Maps of the LQs at the tract level $1992-2011$

In both cases, there seem to be a decreasing concentration of high social groups and symmetrically increasing concentration of low social groups from centre to periphery. Although the geographies of census tracts have changed between censuses, our aggregation into stable district levels confirms those spatial patterns of concentration and their stability over time (Figure 4). 
Figure 4. Maps of the LQs at the district level 1992 - 2011

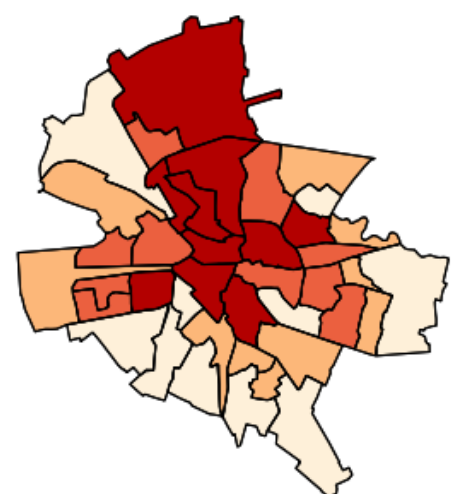

1992 LQ High
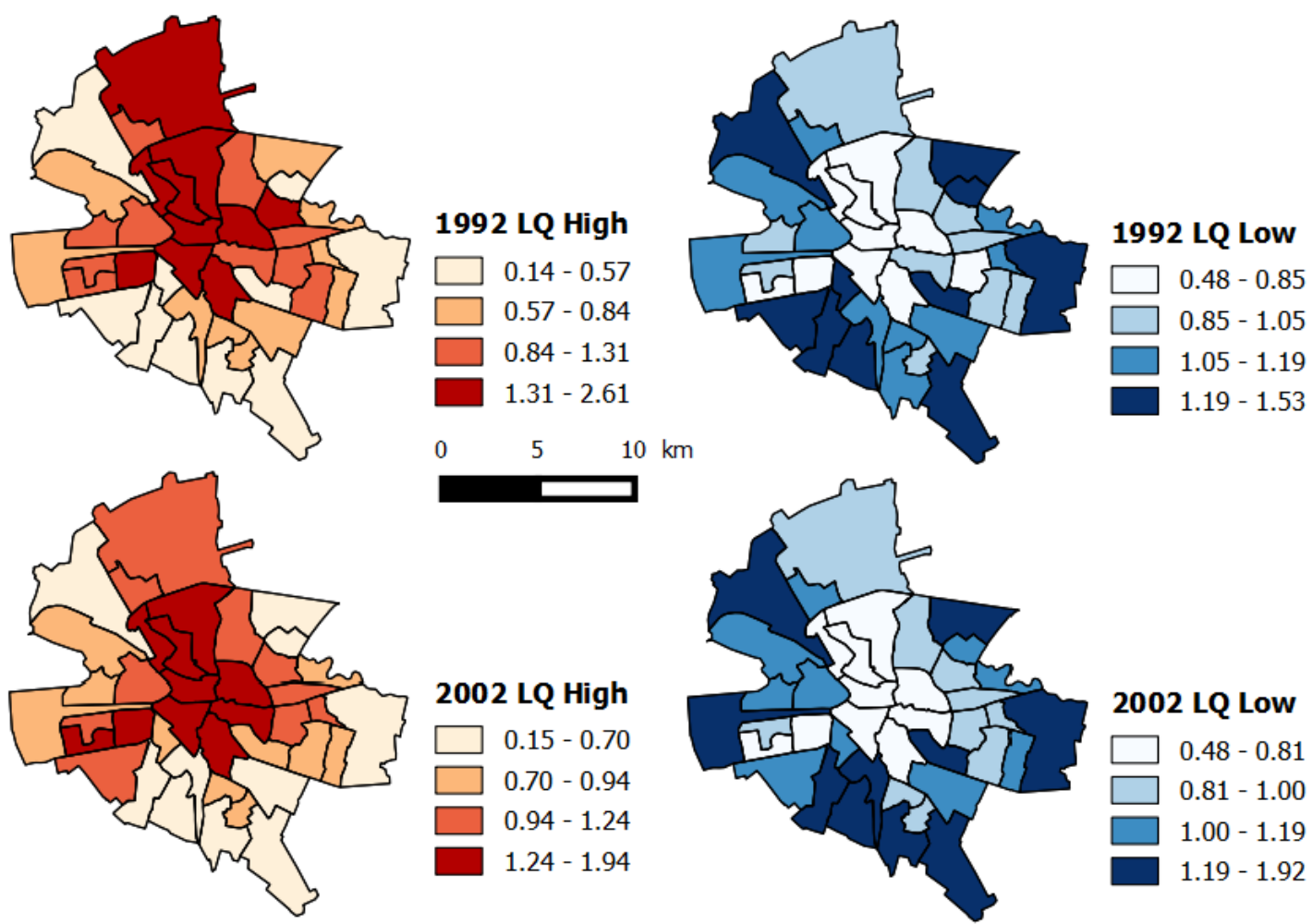

2002 LQ High

$0.15-0.70$

$0.70-0.94$

$0.94-1.24$

$1.24-1.94$

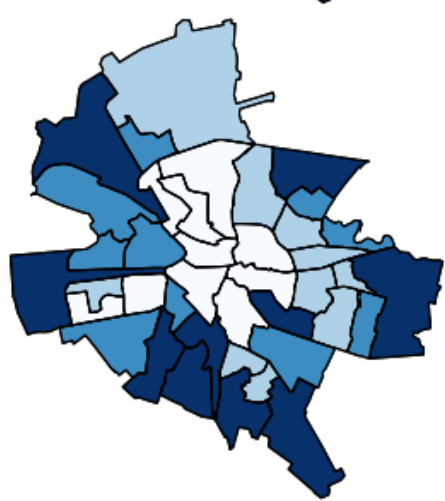

2002 LQ Low
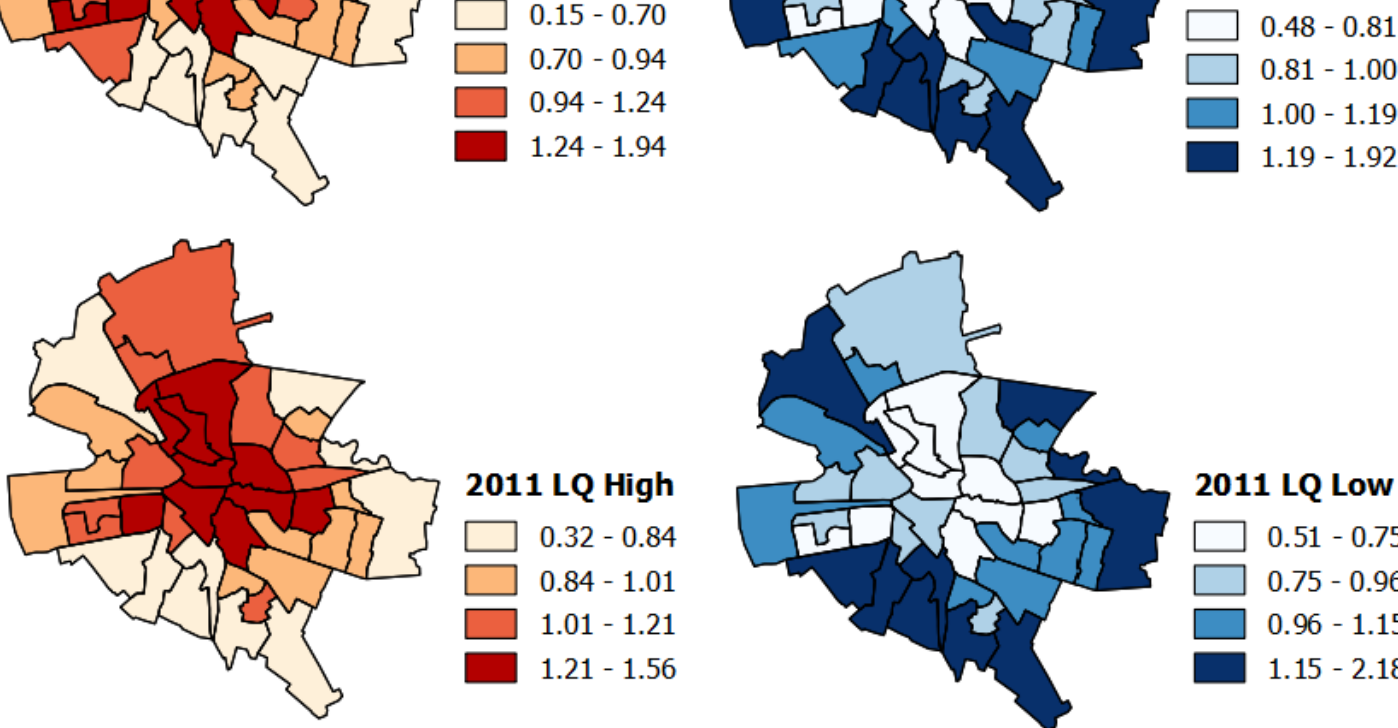

2011 LQ High

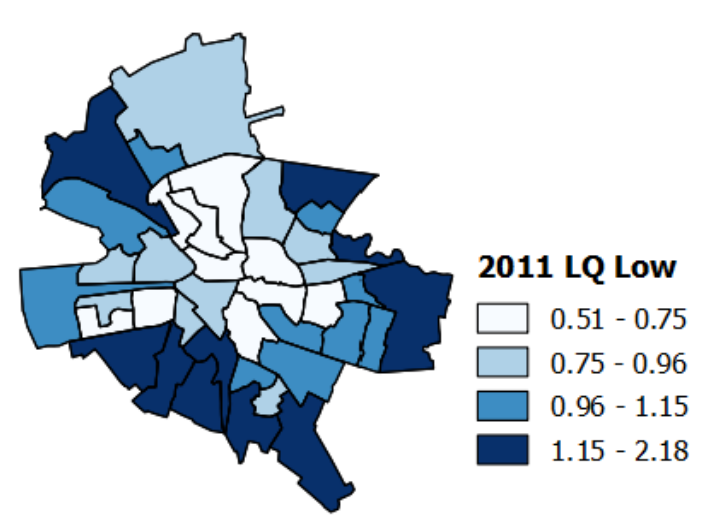

2011 LQ Low

$0.32-0.84$

$0.84-1.01$

$1.01-1.21$

$1.21-1.56$

The concentration of the higher group coincides with the best-quality pre-socialist housing: the villas in the North, the surviving bourgeois housing in the centre, and the better-quality buildings from the Ceauşescu period, in the centre around the monumental "Civic Centre" and to its western (Drumul Taberei) and eastern (Balta Albă, Titan) vicinities. The prestige and popularity of such areas have consolidated since the demise of communism (Chelcea, 2006). Despite some centrifugal movements reportedly gaining momentum after 2000 (Pătroescu et al., 2011) and the heavy transformation of the employment structure, the spatial patterns have remained relative ly stable throughout the transition. In fact, a slight centripetal movement of the high social group can be linked to some 'repellent' factors in the North, with the extension of the Băneasa airport in the 1990s and the forest clearing to give room to a shopping and business complex after 
2006, both fostering traffic and congestion (Ianoş et al., 2016). Some 'attractor' factors are also at play with the rehabilitation of the historical centre and the conjunctive eviction of the Roma population and underclass tenants around 2007 giving rise to gentrification and touristification (Chelcea et al., 2015).

The lower social categories display a nearly inverse spatial pattern. They are concentrating in the peripheries in the low-quality large housing projects from the 1960s and the self-provided houses neighbouring the vast socialist industrial complexes. Contrasting $w$ ith the estates from the late 1970s and 1980s still hous ing medium to higher social categories, the poor-quality blocks from the 1960s gave rise to underclass ghettos after socialism, such as the former workers' dormitories in the Ferentari district in the south west becoming one of the hot spot of the Roma population (Mionel and Negut, 2011). The other one was in the historical core and around the "Civic Centre" as Roma and squatters moved in as Ceauşescu's destructions progressed (Pătroescu et al., 2011). For the low social group as well, the spatial patterns have remained relatively stable throughout the transition. In the outskirts where the lower categories had flocked in poorquality illegally self-constructed housing, the lack of legal document is an impediment to transactions and residential mobility. They have remained an underclass trap (Marin, 2005). However, some slight changes can be observed, linked to the centripetal movement of the higher group and new developments pushing the lower group away: the 'urbanisation front' a long the major transportation corridor in the western outskirts and around the newly established Văcarești National Park in the south east (Ianoş et al., 2016).

\subsection{Determinants of local socioeconomic segregation patterns}

To test the effect of neighbourhood characteristics on the local patterns of segregation, we ran cross-section econometric models for tracts and districts. Table 4 presents the results at the tract scale. As the dependent variables do not follow normal distribution, the LQs were transformed using a Box-Cox transformation ( $\lambda$ parameter). Consequently, we can only compare the direction of each predictor, whether it has a negative or a positive effect on residential concentration, not the effect sizes from the different models. In the results of the spatial lag models, impact measures reflect the effect of a particular explanatory variable on the dependent variable in a particular unit (direct effects) but also in neighbouring units (indirect effects), while total effects sum the overall effect of an explanatory variable. For both socioeconomic groups, the estimated lag models explain more than 70 percent of variance in the concentration patterns and, unlike in the OLS, their residuals are homoscedastic, the homogeneity of variance respects the model assumptions.

Only two variables are consistently significant in predicting the local patterns of segregation at each time stamp. The higher share of elderly is positive ly associated with the over-representation of the better-off, and negatively related to the concentrations of 
the worse-off. The strongholds of the lower social groups have significantly worse housing conditions, as illustrated by the positive association with the share of housing without running water. For both variables, the indirect effects are just as strong as the direct effects, implying strong spill-over effects. The local effects of these two variables are therefore as strong as their effects on neighbouring tracts.

Table 4. Regression models at the tract level $1992-2011$

\begin{tabular}{|c|c|c|c|c|c|c|c|c|}
\hline \multirow{3}{*}{$\begin{array}{c}1992 \\
160 \text { tracts }\end{array}$} & \multicolumn{4}{|c|}{ LQ High $(\lambda=0.32)$} & \multicolumn{4}{|c|}{ LQ Low $(\lambda=1.13)$} \\
\hline & \multirow[t]{2}{*}{ OLS } & \multicolumn{3}{|c|}{ Spatial Lag } & \multirow[t]{2}{*}{ OLS } & \multicolumn{3}{|c|}{ Spatial Lag } \\
\hline & & direct & indirect & Total & & direct & indirect & total \\
\hline Over 65 years & $0.04 * * *$ & $0.027 * * *$ & $0.027 * * *$ & $0.054^{* * *}$ & $-0.018 * * *$ & $-0.013 * * *$ & $-0.011 * * *$ & $0.024 * * *$ \\
\hline Before 1945 & $0.007 * * *$ & $0.004 * * *$ & $0.004 * * *$ & $0.007 * * *$ & $-0.002 * * *$ & $-0.001 * *$ & $-0.0008 * *$ & $-0.0019 * *$ \\
\hline \multicolumn{9}{|l|}{ After 1990} \\
\hline No running water & $-0.03 * * *$ & $-0.0211 * * *$ & $-0.020 * * *$ & $-0.042 * * *$ & $0.011^{* * *}$ & $0.009 * * *$ & $0.008^{* * *}$ & $0.017 * * *$ \\
\hline Rent & $-0.01 * * *$ & $-0.01 * * *$ & $-0.01 * * *$ & $-0.019 * * *$ & $0.005^{* * *}$ & $0.005 * * *$ & $0.004 * * *$ & $0.009 * * *$ \\
\hline \multicolumn{9}{|l|}{ Green areas } \\
\hline Industrial land & & $-0.004 *$ & -0.004 & $-0.008 * *$ & $0.002^{\prime}$ & $0.002^{* *}$ & $0.002^{* *}$ & $0.004 * *$ \\
\hline Constant & $-0.223 * *$ & \multicolumn{3}{|c|}{0.029} & -0.038 & \multicolumn{3}{|c|}{$0.002^{*}$} \\
\hline$\rho$ & & \multicolumn{3}{|c|}{$0.497 * * *$} & & \multicolumn{3}{|c|}{$0.459 * * *$} \\
\hline $\mathrm{r}^{2}$ & 0.75 & \multicolumn{3}{|c|}{0.85} & 0.76 & \multicolumn{3}{|c|}{0.84} \\
\hline Moran's I & $0.274 * * *$ & & & & $0.283^{* * *}$ & & & \\
\hline Breusch-Pagan test & $12.2^{\prime}$ & \multicolumn{3}{|c|}{9.0} & $13.6^{\prime}$ & \multicolumn{3}{|c|}{11.2} \\
\hline
\end{tabular}

\begin{tabular}{|c|c|c|c|c|c|c|c|c|}
\hline \multirow{3}{*}{$\begin{array}{c}2002 \\
151 \text { tracts }\end{array}$} & \multicolumn{4}{|c|}{ LQ High $(\lambda=0.71)$} & \multicolumn{4}{|c|}{ LQ Low $(\lambda=0.52)$} \\
\hline & \multirow[t]{2}{*}{ OLS } & \multicolumn{3}{|c|}{ Spatial Lag } & \multirow[t]{2}{*}{ OLS } & \multicolumn{3}{|c|}{ Spatial Lag } \\
\hline & & direct & indirect & total & & direct & indirect & total \\
\hline Over 65 years & $3.5^{* * * *}$ & $2.33 * * * *$ & $3.68 * * * *$ & $6.01^{* * * *}$ & $-2.4^{* * * *}$ & $-1.67 * * * *$ & $-1.43 * * *$ & $-3.10 * * * *$ \\
\hline Before 1945 & $0.3^{* * *}$ & & & & $-0.02 * *$ & & & \\
\hline \multicolumn{9}{|l|}{ After 1990} \\
\hline No running water & $-1.8^{* * * *}$ & $-1.40 * * * *$ & $-2.22 * * * *$ & $-3.62 * * * *$ & $1.4^{* * * *}$ & $1.14^{* * * *}$ & $0.97 * * *$ & $2.12 * * * *$ \\
\hline Rent & $1.1^{* * *}$ & & & & $-1.1 * * * *$ & $-0.74 * * * *$ & $-0.63 * *$ & $-1.37 * * * *$ \\
\hline \multicolumn{9}{|l|}{ Green areas } \\
\hline \multicolumn{9}{|l|}{ Industrial land } \\
\hline Constant & $-0.59 * * * *$ & \multicolumn{3}{|c|}{$-0.24 * * * *$} & $0.34 * * *$ & \multicolumn{3}{|c|}{$0.18^{* * *}$} \\
\hline$\rho$ & & \multicolumn{3}{|c|}{$0.66 * * * *$} & & \multicolumn{3}{|c|}{$0.49 * * *$} \\
\hline $\mathrm{r}^{2}$ & 0.67 & \multicolumn{3}{|c|}{0.83} & 0.68 & \multicolumn{3}{|c|}{0.76} \\
\hline Moran's I & $0.319 * * * *$ & & & & $0.228 * * * *$ & & & \\
\hline Breusch-Pagan test & 2.5 & \multicolumn{3}{|c|}{6.6} & 6.2 & \multicolumn{3}{|c|}{11.3} \\
\hline
\end{tabular}




\begin{tabular}{|c|c|c|c|c|c|c|c|c|}
\hline \multirow{3}{*}{$\begin{array}{c}2011 \\
131 \text { tracts }\end{array}$} & \multicolumn{4}{|c|}{ LQ High $(\lambda=1.21)$} & \multicolumn{4}{|c|}{ LQ Low $(\lambda=0.11)$} \\
\hline & \multirow[t]{2}{*}{ OLS } & \multicolumn{3}{|c|}{ Spatial Lag } & \multirow[t]{2}{*}{ OLS } & \multicolumn{3}{|c|}{ Spatial Lag } \\
\hline & & direct & indirect & total & & direct & indirect & total \\
\hline Over 65 years & $2.6^{* * * *}$ & $1.72^{* * * *}$ & $1.84^{* * * *}$ & $3.56^{* * * *}$ & $-3.56 * * * *$ & $-2.49 * * * *$ & $-2.06 * * *$ & $-4.56 * * * *$ \\
\hline Before 1945 & $0.4^{* * *}$ & $0.27 * * * *$ & $0.28^{* *}$ & $0.56^{* * *}$ & $-0.22 *$ & $-0.20 * *$ & & $-0.37 * *$ \\
\hline After 1990 & & $0.24 * *$ & & $0.49 *$ & & $-0.31 * *$ & & $-0.56 *$ \\
\hline No running water & $-9.6^{* * * *}$ & $-0.19 * * * *$ & $-0.21 * * *$ & $-0.40 * * *$ & $7.1^{* * *}$ & $2.13^{* * * *}$ & $2.16^{* * *}$ & $4.29 * * * *$ \\
\hline Rent & $2.9 * * * *$ & & & & $-2.45^{* *}$ & & & \\
\hline Green areas & $0.003 * *$ & $0.003^{* * * *}$ & $0.003 * * *$ & $0.007^{* * *}$ & $-0.002^{\prime}$ & $-0.002^{* *}$ & & $-0.004 *$ \\
\hline Industrial land & $-0.003 * *$ & & & & $0.005^{* * *}$ & & & \\
\hline Constants & $-0.582^{* * *}$ & $-0.385^{* * *}$ & & & $0.591^{* * * *}$ & $0.422 * * * *$ & & \\
\hline$\rho$ & & \multicolumn{3}{|c|}{$0.589 * * * *$} & & \multicolumn{3}{|c|}{$0.526^{* * * *}$} \\
\hline $\mathrm{r}^{2}$ & 0.63 & \multicolumn{3}{|c|}{0.76} & 0.58 & \multicolumn{3}{|c|}{0.68} \\
\hline Moran's I & $0.278^{* * * *}$ & & & & $0.248^{* * * *}$ & & & \\
\hline Breusch-Pagan test & 9.3 & \multicolumn{3}{|c|}{9.6} & 8.0 & \multicolumn{3}{|c|}{7.5} \\
\hline
\end{tabular}

$' 0,1 * 0,05 * * 0,01 * * * 0,001 * * * * 0,0001$

Right after the collapse of socialism, in 1992, significant effects also arose from the share of historical housing, tenure structure, and environmental conditions. The share of housing before 1945 is positively associated with the concentration of the higher social group and has an adverse effect on the lower social group. The tenure structure of housing has a similar effect, with the share of owner-occupied hous ing being a good predictor of higher social status areas, rentals being mediated by public housing. Finally, the lower social groups were overrepresented within neighbourhoods with a higher share of industry, and also in the areas neighbouring industrial districts. While higher social categories were generally avoiding such neighbourhoods, the indirect effects are not significant, meaning that the 'repellent' effect of industry was confined to the local (tract) scale for the better-off.

One decade after socialism, the 2002 results reveal that housing stock and environmental variables lose statistical significance. Surprisingly, compared to the situation in 1992, the effect of tenure structure changed its sign and its effect was limited to the lower social groups' patterns of concentration. After the privatisation of housing to sitting tenants in the 1990s, the lower social group no longer dominated in the areas with higher share of rented housing, as the number of rentals shrank and was increasingly turning to the market.

Two decades after socialism, in 2011, the lower social group was underrepresented in historical areas. The historical housing stock had significant positive direct and indirect effects on the concentration of the better-off, meaning they were overrepresented in those tracts and their surroundings. The areas with new residential tissue built after socialism 
had a similar effect, a lbeit limited at the local scale. Interestingly, green areas started to have direct and indirect effects on the local patterns of segregation. Not only the higher social group concentrated in the tracts with higher shares of green areas, it was also overrepresented in the neighbouring tracts.

Table 5. Regression models at the dis tricts scale $1992-2011$

\begin{tabular}{|l|c|c|c|c|c|c|}
\hline \multirow{2}{*}{39 dis tricts } & \multicolumn{2}{|c|}{1992} & \multicolumn{2}{c|}{2002} & \multicolumn{2}{c|}{2011} \\
\cline { 2 - 7 } & LQ High & LQ Low & LQ High & LQ Low & LQ High & LQ Low \\
\hline Over 65 years & $0.04^{* *}$ & $-0.02^{* *}$ & $0.03^{* *}$ & $-0.03^{* * *}$ & $0.02^{* * *}$ & $-0.03^{* * *}$ \\
\hline Before 1945 & $0.008^{* *}$ & $-0.002^{*}$ & & & $0.007^{* * *}$ & $-0.006^{*}$ \\
\hline After 1990 & & & & & $0.006^{*}$ & \\
\hline No running water & $-0.02^{* * *}$ & $0.01^{* * *}$ & $-0.01^{* * *}$ & $0.01^{* * *}$ & $-0.1^{* * *}$ & $0.2^{* * *}$ \\
\hline Rent & $-0.01^{* *}$ & $0.006^{* *}$ & $0.03^{* *}$ & $-0.01^{*}$ & $0.03^{*}$ & \\
\hline Green areas & & & $0.007^{*}$ & $-0.005^{*}$ & $0.005^{* *}$ & $-0.005^{*}$ \\
\hline Industrial land & & & & & & \\
\hline $\mathrm{r}^{2}$ & 0.81 & 0.80 & 0.80 & 0.81 & 0.89 & 0.87 \\
\hline Breusch-Pagan test & $13.9^{\prime}$ & $13.7^{\prime}$ & 8.0 & 11.7 & 4.9 & 3.1 \\
\hline
\end{tabular}

'0,1*0,05** 0,01*** 0,001

At the district scale, the residuals of the OLS model are not spatially autocorrelated and do not suffer from heteroscedastic ity (Table 5). The results generally confirm the same relationship between local segregation patterns and ne ighbourhood characteristics. The effects of demographic, building stock and housing variables seem therefore scale invariant. However, this is not the case of environmental factors. The share of industrial land loses statistical significance at the district scale, further confirming that its effect on segregation patterns is confined to the local level. In turn, green areas became a significant predictor of higher social areas earlier, while the lower social group had significantly less green areas already during the first decade after socialism.

\section{Discussion}

In Bucharest, the relationship between the local patterns of socioeconomic concentration and ne ighbourhood characteristics is significant, but is not stable over time. While previous studies, often limited to one time point, have reported inconsistent results, sometimes concluding that the association between environmental quality and residential segregation is either unclear or nonexistent, our innovative research design reveals that both 'attractor' and 'repellent' environmental factors are playing a significant part at different scales, a though with varying impacts throughout the succeeding stages of the post-socialist transition. It has been argued that previous mixed findings regarding the association between segregation and environmental factors might arise from 
methodological shortcomings (Park et al., 2017; Frey, 2017). Overcoming them reveals that the positive (and expected) effect of green areas on the concentration patterns of the higher social profiles in the post-socia list city requires an extended development of market economy.

Despite raising income inequalities, radical changes in the occupational composition and population shrinkage during the two decades of transition after socia lism, the level of socioeconomic segregation did not seem to increase in Bucharest. On the contrary, after marginal changes in the 1990s (Marcińczak et al. 2014), residential segregation unexpectedly continued to decline during the second decade of the transition (until 2011). Keeping in mind the data constraints, we have confirmed these trends at different scales (tracts and districts).

Bucharest might thus give the staggering impression that the post-socialist transition is in fact "equalising" the neighbourhood social profiles and mixing population groups. Not only might this cast doubt on the popular notion that grow ing income inequality implies a more acute residential segregation (van Kempen, 2007; Tammmaru et al. 2016), it also questions the fashionable assumption that the social cost of the post-socialist transition fosters socio-spatial polarisation or even dua lisation (Bernt et al., 2015; Sýkora and Bouzarovski, 2012; Hamilton et al., 2005). Bucharest is a sheer example of professionalisation resulting in a more mixed social profile. One could assume that the more "hesitant" the transition from socialism to capitalism, the longer the "delay" between inc ome inequality and residential segregation (Marcińc zak et al., 2014). However, Romania entered the European Union in 2007 and most impediments to housing market and residential mobility were removed by 2005-2006: the absence of a trend reversal by 2011 does not support a "de lay" any more.

Apart from environmental factors, other neighbourhood characteristics have a significant effect on the local patterns of soc ioeconomic segregation, most notably the share of elderly. The demographic group was used as a proxy for a wider demographic context, as it is positive ly correlated to single households while negatively correlated to the share of people under 15 years and larger households (5 people and above). The elderly appear as the winners of the "hesitant" transition, at least those already concentrated in older housing in the central and northern areas before the transition (Che lcea et al. 2015). There is however an underlying selection as the less influent, less educated, more recently arrived, thus more likely to live in less attractive neighbourhoods and in the outskirts during socialism, have been returning to the ir retrocessioned land in their former villages trying to survive from subsistence agriculture (Chelcea, 2006). The former elite were able to stay in the same fashionable housing nationalised by the socialists in 1948 at least until the end of the legal protection against eviction in 2005. The "hesitant" trans ition has preserved this socioeconomic segregation and its geographies in Bucharest until the mortgage market took off in 2006. Only in 2011 the newer housing, built after socialism, 
finally attracted high social status population. This supports findings from other postsocialist countries that post-1990 housing allows the better-off to manifest the ir purchasing power (Marcińczak et al. 2017; Holm et al. 2015). Conversely, worse housing conditions are a strong predictor of the concentration of the lower social group. The share of housing without running water (almost 10\% in Bucharest in 1992) is a significant determinant of the lower group strongholds at both tract and district scales, consistently throughout the two decades of the transition.

This suggests that despite the eye catching continuous trend of desegregation, the poor are in fact "trapped" in the neighbourhoods with the worst conditions. Lack of running water was an indicator of a broader situation of deprivation and while its effects remained strong and consistent all over the period, environmental variables are the determinants whose influe nce have been changing the most. At the onset of the transition, the close proximity of industrial land was both a 'repellent' for the higher social group and a predictor of the concentration of the lower social group. This directly reflects the situation during socialis $m$, when low-quality large hous ing projects were hastily built right around industrial complexes to house the workers and lower social groups had no choice but to self-construct wood and cob housing lacking basic amenities further out, while the heavy industry was keeping the higher social groups at bay. It is however surpris ing that their 'repellent' effect is not significant any more after 2000, when the better connected plants started to be redeveloped, as if the novelty of the new shopping malls and business parks erased the environmental cost of the socialist heritage and that less visible water and soil pollution is now easier to overlook.

Conversely, while the proximity of green areas was not significant at the beginning of the transition, it had increasing effects on the local patterns of socioeconomic segregation, 'attracting' the higher and 'repelling' the lower social groups, first at the ne ighbourhood, then at the local scale. The positive effect of the access to green areas on real estate prices has been demonstrated to emerge early in the transition for other post-socialist cities (Czembrowski and Kronenberg 2016). Whilst in Bucharest the quality of parks depredated at the beguiling of the transition before some redevelopments in the late 2000s, all green spaces were found to have health benefits (Sirodoev et al, 2015). The increasing convergence of the effects of housing conditions and environmental factors on local patterns of segregation at the two different scales reveals that, despite the overall desegregation trend, the lower soc ial categories are in fact captive of the less desirable areas in the neighbourhoods with the worse environmental conditions.

\section{Conclusion}

How helpful is the post-socialist transition in the environmental justice debate? During the "hesitant" transition, the slow (re)emergence of a real estate and housing market 
after socialism was to give a unique chance to observe whether poor environmental conditions, hazardous facilities, low cost housing or soc ially marginalized groups came first. Despite the data limitations in Bucharest, our findings suggest that during as well as after socialism the lower socioeconomic group are being "trapped" in the neighbourhoods with the worst environmental conditions. Overcoming previous methodological shortcomings, our approach shows the increasing impact of the proximity of green areas and symmetrically decreasing effect of the closeness of noxious facilities on the segregation patterns as the market matures. Whereas our study reveals significant relationships between environmental factors and the local patterns of segregation at different spatial scales, a longitudinal, and preferably individual-level statistical information might be needed to draw firmer conclusions. So, what does environmental justice bring to the segregation studies in the post-soc ialist context? Despite the apparently continuous desegregation trend in Bucharest, and even when controlling for the presence and proximity of demographic, tenure and housing predictors, environmental factors play an increasing role in shaping the local segregation patterns. This would suggest the need for consideration of the environmental factors in policies aimed at mitigating the social cost of the transition as well as residential segregation. This should also lead to use descriptive measures of segregation more cautious ly and to explore the relations hip between neighbourhood characteristics, environmental conditions and the local patterns of segregation instead.

\section{References}

Andersen H. S. (2003) Urban Sores. On the interaction between segregation, urban decay and deprived neighbourhoods, London: Ashgate Publishers.

Anonymous, Rufat, S. (2015). Open Data, Political Cris is and Guerrilla Cartography. ACME: An International Journal for Critical Geographies, 14(1), 260-282.

Arbaci, S. (2007). Ethnic segregation, housing systems and welfare regimes in Europe. International Journal of Housing Policy, 7(4), 401-433.

Ardeshiri, A., Ardeshiri, M., Radfar, M., Hamidian Shormasty, O. (2016). The values and benefits of environmental elements on housing rents. Habitat International, 55, 67-78.

Armaş, I., Gavriş, A. (2016). Census-based social vulnerability assessment for Bucharest. Procedia Environmental Sciences, 32, 138-146.

Basolo, V., Yerena, A. (2017). Residential mobility of low-income, subsidized households: a synthesis of explanatory framew orks. Housing Studies, 32(6), 841-862.

Bernt, M., Gentile, M., Marcińczak, S. (2015). Gentrification in post-communist countries: An introduction. Geografie, 102(2), 104-112.

Boone, C. G., Fragkias, M., Buckley, G. L., Grove, J. M. (2014). A long view of polluting industry and environmental justice in Baltimore. Cities, 36, 41-49.

Brown, L. A., Chung, S. Y. (2008). Market-led pluralism: Rethinking our understanding of racial/ethnic spatial patterning in U.S. cities. Annals of the Association of American Geographers, 98(1), 180-212. 
Bullard, R. D. (1990). Ecological inequities and the New South: Black communities under siege. The Journal of Ethnic Studies, 17(4), 101.

Chaisty, P., Whitefield, S. (2015). Attitudes towards the environment: are post-communist societies (still) different? Environmental Politics, 24(4), 598-616.

Chelcea, L., Popescu, R., Cristea, D. (2015). Who Are The Gentrifiers and How Do They Change Central City Neighbourhoods? Privatization, Commodification, and Gentrification in Bucharest. Geografie, 120, 113-133.

Chelcea, L. (2006). Marginal groups in central places: gentrification, property rights and postsocialist primitive accumulation (Bucharest, Romania). Social changes and social sustainability in historical urban centres, 127-146.

Cohen, M., Baudoin, R., Palibrk, M., Persyn, N., \& Rhein, C. (2012). Urban biodiversity and social inequalities in built-up cities: New evidences, next questions. The example of Paris, France. Landscape and Urban Planning, 106(3), 277-287.

Cook, I. R., Swyngedouw, E. (2012). Cities, social cohesion and the environment: tow ards a future research agenda. Urban Studies, 49(9), 1959-1979.

Coulter, R., Van Ham, M. (2013). Following people through time: An analysis of individual residential mobility biographies. Housing Studies, 28(7), 1037-1055.

Czembrowski, P., Kronenberg, J. (2016). Hedonic pricing and different urban green space types and sizes: insights into the discussion on valuing ecosystem services. Landscape and Urban Planning, 146, 11-19.

Davis, M. (2006). Planet of Slums, New York, Verso.

Dumitrache, L., Zamfir, D., Nae, M. Simion, G., Stoica, I. V. (2016). The Urban Nexus: Contradictions and Dilemmas of (Post) Communist (Sub) Urbanization in Romania. Human Geographies, 10(1), 39.

Florida, R. (2017). The new urban crisis: How our cities are increasing inequality, deepening segregation, and failing the middle class and what we can do about it. Hachette UK.

Frey, N. (2017). Equity in the distribution of urban environmental amenities: the case of Washington, DC. Urban Geography, 38(10), 1534-1549.

Grădinaru S.R., Iojă I.C., Onose D.A., Gavrilidis A.A., Pătru-Stupariu I., Kienast F., Hersperger A.M. (2014), Land abandonment as a precursor of built-up development at the sprawling periphery of former socialist cities, Ecological Indicators, 57, 305-313

Ham ilton, F., Andrews, K., Pichler-Milanović, N. (2005). Transformation of cities in central and eastern Europe. Tokyo, United Nations University Press.

Holm, A., Marcińczak, S., Ogrodowczyk, A. (2015). New-build gentrification in the post-socialist city: Łodź and Leipzig two decades after socialism. Geografie, 120(2), 164-187.

Houston, D., Li, W., Wu, J. (2014). Disparities in exposure to automobile and truck traffic and vehicle emissions near the Los Angeles-Long Beach port complex. American journal of public health, 104(1), 156-164.

Ianoş, I., Sîrodoev, I., Pascariu, G., Henebry, G. (2016). Divergent patterns of built-up urban space growth following post-socialist changes. Urban Studies, 53(15), 3172-3188.

Iojă I.C., Rozylowicz L., Pătroescu M., Nita M., Vanau, G. (2011). Dog walkers’ vs. other park visitors' perceptions: The importance of planning sustainable urban parks in Bucharest, Romania, Landscape and Urban Planning, 103 (1), 74-82

Kovacs, Z., Herfert, G. (2012). Development pathways of large housing estates in post-socialist cities: An international comparison. Housing Studies, 27(3), 324-342.

Landrine, H., Corral, I. (2009). Separate and unequal: residential segregation and black health disparities. Ethnicity \& disease, 19(2), 179. 
Łaszkiewicz, E., Kronenberg, J., Marcińczak, S. (2017). Attached to or bound to a place? The impact of green space availability on residential duration: The environmental justice perspective. Ecosystem Services, 30, 309-317.

Maloutas, T., Fujita, K. (2012). Residential segregation around the world. Why context matters. London, Ashgate.

Marcińczak, S., Tammaru, T., Ogrodowczyk, A. (2017). Exploring patterns of socioeconomic residential intermixing in Tallinn. Cities, (67), 95-103.

Marcińczak, S., Musterd, S., van Ham, M., Tammaru, T. 2016 Inequality and rising levels of socioeconomic segregation. In Socio-economic segregation in European capital cities: East meets West. London: Routledge: 358-382.

Marcińczak, S., Tammaru, T., Novák, J., Gentile, M., Kovács, Z., Temelová, J., Szabó, B. (2015). Patterns of socioeconomic segregation in the capital cities of fast-track reforming postsocialist countries. Annals of the Association of American Geographers, 105(1), 183-202.

Marcińczak, S., Gentile, M., Rufat, S., Chelcea, L. (2014). Urban Geographies of Hesitant Transition: Tracing Socioeconomic Segregation in Post-Ceauşescu Bucharest. International Journal of Urban and Regional Research, 38(4), 1399-1417.

Marcińczak, S., Gentile, M., Stępniak, M. (2013). Paradoxes of (post)socialist segregation: Metropolitan sociospatial divisions under socialism and after in Poland. Urban Geography 34(3), 327-352.

Marcińczak, S., Sagan, I. (2012). The socio-spatial restructuring of Łódź, Urban Studies 48(9), 1789-1809.

Marin, V. (2005). Inhabiting the outskirts of Bucharest: 'old'socialist housing estates versus 'new' capitalist suburbia developments. Paths of Urban Transformation: The European City in Transition, 121-141.

Massey, D. (2005). For space. London: Sage.

Mionel, V., Neguţ, S. (2011). The Socio-Spatial Dimension of the Bucharest Ghettos. Transylvanian Review of Administrative Sciences, 7(33), 197-217.

Mohai, P., Saha, R. (2006). Reassessing racial and socioeconomic disparities in environmental justice research. Demography, 43(2), 383-399.

Morello-Frosch R, Jesdale B. (2006). Separate and unequal: residential segregation and air quality in the metropolitan US. Environmental health perspectives, 114(3), 386-94.

Morello-Frosch, R. A. (2002). Discrimination and the political economy of environmental inequality. Environment and Planning C, 20(4), 477-496.

Musterd, S., Tammaru, T., Van Ham, M., \& Marcińczak, S. (2016). A multi-factor approach to understanding socio-economic segregation in European capital cities. Taylor \& Francis.

Padilla, C. M., Kihal-Talantikite, W., Vieira, V. M., Rossello, P., Le Nir, G., Zmirou-Navier, D., \& Deguen, S. (2014). Air quality and social deprivation in four French metropolitan areas - A localized spatio-temporal environmental inequality analysis. Environmental research, 134, 315-324.

Panduro, T.E, Veie, K.L. (2013). Classification and valuation of urban green spaces-a hedonic house price valuation. Landscape and Urban planning, 120, 119-128.

Park, Y. M., Kwan, M. P. (2017). Multi-Contextual Segregation and Environmental Justice Research: Toward Fine-Scale Spatiotemporal Approaches. International journal of environmental research and public health, 14(10), 1205.

Pastor M, Sadd J, Hipp J. (2001). Which came first? Toxic facilities, minority move-in, and environmental justice. Journal of urban affairs. 23(1), 1-21.

Pătroescu, M., Vacircnau, G., Nita, M. R., Iojă, C., Iojă, A. (2011). Land Use Change in the Bucharest Metropolitan Area and its Impacts on the Quality of the Environment in Residential Developments. Forum geografic, 10(1), 177-186. 
Pavlínek, P. and Pickles, J. (2000). Environmental Transitions: Transformation and Ecological Defence in Central and Eastern Europe. London: Routledge.

Reardon, S. F., Bischoff, K. (2011). Income inequality and income segregation. American Journal of Sociology, 116(4), 1092-1153.

Rufat, S. (2013). Spectroscopy of Urban Vulnerability. Annals of the Association of American Geographers, 103(3), 505-525.

Simion, G. (2016). Effects of postsocialist deindustrialization in Central and Eastern Europe: Results of an industrial site survey in Bucharest, Romania. Human Geographies, 10(1), 79-93.

Sirodoev, I., Cheval, S., Dumitrescu, A., Merciu, C., Vaidianu, N., Paraschiv, M., Prefac, Z. (2015). Contribution of the built-up space to the creation of urban heat island in Bucharest municipality. Journal of Environmental Protection \& Ecology, 16(4), 1337-1343.

South S. J., Crowder K., Pais J. (2011) Metropolitan structure and neighborhood attainment: Exploring intermetropolitan variation in racial residential segregation, Demography 48(4): 1263-1292.

Stanilov, K., Sykora, L. (2014). Confronting suburbanization. Urban decentralization in postsocialist central and eastern Europe. Oxford: Wiley Blackwell.

Stanilov, K. (2007). The Post-Socialist City. Springer, Dordrecht.

Suditu, B., Vâlceanu, D. G. (2013). Informal settlements and squatting in Romania: Socio-spatial patterns and typologies. Human Geographies, 7(2), 65-75.

Sykora, L. (2009). New socio-spatial formations: Places of residential segregation and separation in Czechia. Tijdschrift voor Economische en Sociale Geografie, 100(4), 417-435.

Sýkora, L., Bouzarovski, S. (2012). Multiple transformations: Conceptualising the post-communist urban transition. Urban Studies, 49(1), 43-60.

Taylor, D. (2014). Toxic communities: Environmental racism, industrial pollution, and residential mobility. NYU Press.

Tammaru, T., Musterd, S., Van Ham, M., Marcińczak, S. (2016). A multi-factor approach to understanding socio-economic segregation in European capital cities. Taylor \& Francis.

van Gent, W., Musterd, S. (2016). Class, migrants, and the European city: Spatial impacts of structural changes in early twenty-first century Amsterdam. Journal of Ethnic and Migration Studies, 42(6), 893-912.

van Kempen, R. (2007). Divided cities in the 21st century: Challenging the importance of globalization. Journal of Housing and Built Environment, 22(1), 13-31.

van Kempen R., Murie A. (2009) The new divided city: changing patterns in European cities. Tijdschrift voor Economische en Sociale Geografie 100(4), 377-398.

Whitehead, M. (2005) Between the marvellous and the mundane: everyday life in the socialist city and the politics of the environment, Environment and Planning D, 23, 273-294.

Wong, D. W., Lasus, H., Falk, R. F. (1999). Exploring the variability of segregation index D with scale and zonal systems: an analysis of thirty US cities. Environment and Planning A, 31(3), 507-522. 